knowledge of electricians. If, therefore, my article in NATURE, at a time when electric currents of great strength are being so widely introduced into practical working, has contributed to make electricians acquainted with this form of galvanometer, I shall not regret the time I have spent in theoretically and experimentally investigatiing this subject. Prof. Pickering alludes in his book to the improper dip motions of the needle as a defect in his form of galvanometer; I think I have obviated this by pivoting the axis of the needle at both ends. Since communicating the results obtained with my experimental instrument, more elaborate instruments have been constructed and found very useful in many instances where the ordinary forms of galvanometers would not have answered the purpose. EUGEN OBACH

Woolwich, November 19

\section{Utilisation of the African Elephant}

I have just read some remarks in NATURE (vol. xix. p. 54) on the utilisation of the African elephant, which I think are worth considering. Judging from the specimens in the Regent's Park Gardens, which I suppose have not been selected in any way, and are there fore only average samples of the African species, I should say that the African elephant would prove hardier and capable of more work than the general run of Indian elephants. I was surprised to find that the two African elephants I saw in the Regent's Park were what the mahouts call "Dohara Band," which I would translate "double constitution." I do not think that more than five per cent. of Indian elephants are placed in this class. It is very rare indeed to see an elephant of this class in a Government Feelkanah, or in the hands of any European, because wealthy natives value them so highly and give such enormous prices for them, that even when caught by a Government keddah officer they are often sold on account of the fancy prices they fetch. The "Dohara Band" elephant will do a wonderful amount of work on a small quantity of food, and stands fatigue and exposure to the sun far better than any other sori.

To commence elephant-catching operations in Africa, six "koonkies," i.e., elephants trained for catching purposes, would be required, and about twenty men from Assam or some other jungle district of Bengal would be sufficient. With this establishment it would be possible to catch and train at least two hundred elephants in the course of twelve months.

H. L. JENKINS

Clanacombe, Kingsbridge, Scuth Devon, November 24

\section{OUR ASTRONOMICAL COLUMN}

ORBITS OF BINARY STARS. - In a communication to The Observatory, Dr. Doberck, of Col. Cooper's Observatory, Markree Castle, has summarised the results of the investigations on the orbits of the revolving double stars which have occupied him between three and four years, and which he has conducted with so much skill and laborious application. In a climate where the skies are too irregularly favourable to allow of an astronomer occupying himself wholly upon observations, it would be difficult to name any more interesting work to which he could devote his leisure, than such a revision of the elements of the binary systems. Dr. Doberck's account of bis methods in different cases will be of much service to any one who may engage upon similar researches. He has found no reason to detract from the value of the early, graphical method of Sir John Herschel ; on the contrary, instances are mentioned where it has been of the greatest service in tracing out the general form of the orbit, for correction by more refined processes, as in the difficult case of $\Sigma 1768$ : indeed, Dr. Doberck considers it superior to the second method given by Herschel from its admitting of the weights being approximately taken into account with ease. In a provisional orbit for the close double star $\Sigma 312 \mathrm{I}$, the period assigned is thirty-seven years; at present we know of only two more rapid binaries. Some of [the orbits included in Dr. Doberck's paper, have been made the subject of communications to the Royal Irish Academy, and have been published in the Transactions.

LALANDE's STARS, NOS. 5,499 AND 45,400.--Mr. J. E. Gore writes suggesting variation in both these objects.
In examining the question of variability of any of Lalande's stars, Mr. Gore will find it necessary, in the first instance, to have recourse to the original observations as printed in the "Histoire Céleste," there being many errors in the reduced catalogue. Thus, No. 5,499 appears through a misprint at p. 246 , where the transit at the third wire is given as $2 \mathrm{~h} .47 \mathrm{~m} .45^{\circ} 2 \mathrm{~s}$., instead of 2h. $42 \mathrm{~m} .45^{\circ} 2 \mathrm{~s}$. The star is really No. 788 of Weisse's Bessel. The following star is also thrown out by a similar error in the time of transit, so that Lalande, 5,520, requires a correction of $-5 \mathrm{~m}$. in R.A. With regard to No. 45,400 , the suspicion of rariability is probably occasioned by a misprint in the "Histoire Celeste," since Piazzi, Bessel, and others estimate the magnitude the same as at present.

The ANnUlar Eclipse of JanuaRy 22, 1879.-The first of the annular eclipses of the ensuing year, a return of that of January 10, I86I, which was central in Australia, commences in Uruguay, whence the belt of annular phase traverses the South Atlantic, passing over Tristan d'Acunha, the few inhabitants of which islands may probably be startled by seeing the sun transformed into a narrow luminous ring while he is high in their heavens. The central line crosses the African continent in the direction of Pemba Island, north of Zanzibar, where the annularity will continue nearly three minutes: the middle of the eclipse at $4 \mathrm{~h} .6 \mathrm{~m}$. P.M., local mean time.

\section{GEOGRAPHICAL NOTES}

THE Council of the Royal Geographical Society have determined to commence, on January 1,1879 , the monthly issue of a new series of their Proceedings, under the title of The Proceedings of the Royal Geographical Society and Monthly Record of Geography. The latter part of this title will, we believe, fairly indicate the nature of the contents, which will include the papers read at the evening meetings, original articles, geographical notes, obituary notices, proceedings of geographical societies, and brief analytical notes on new books and maps. Each monthly numbur will be illustrated with one or more maps, and no doubt in this respect endeavours will be made to meet the wants of a public larger than that contained within the ranks of this popular society, which now numbers some 3,400 members.

In connection with this we regret to announce that this month's number of the Geographical Magazine brings the career of that journal to a close. This regret, however, is considerably mitigated by the fact that the new form of the Geographical Society's organ is intended to take the place of the journal which for so many years has been so ably conducted by Mr. C. R. Markhain. Mr. Markham deserves great credit for his disinterestedness in continuing to carry on a journal which aimed so successfully to be the organ of scientific geography in this country. The volumes will form a valuable record of the progress of geography for the period over which they extend. In the December number $\mathrm{Mr}$. Markham gives an account of the career of the journal since its first start as Ocean Highways in 1870 . We trust that the new organ will prove a worthy successor of its predecessor, and that while giving due prominence to geographical news, the conductors will aim at bringing geography under the guidance of sound scientific principles.

THE Church Missionary Society have recently received from Mr. A. M. Mackay, of their Nyanza Expedition, the journal of his experiences, extending from December $3 \mathrm{I}$, I 877 , to May 16, I878, in which occur some useful suggestions to African travellers, as well as information of considerable interest to geographers. On April $30 \mathrm{Mr}$. Mackay reached Uyui, after a hurried and tedious tramp 